\title{
Perbandingan Aktivitas Belajar Siswa Yang Tinggal di Asrama dan di Luar Asrama Madrasah Aliyah Swasta (MAS) YASTI Singkawang Tahun 2019/2020
}

\author{
Yusida Imran*, Rima Maya Dela* \\ *yusidaimran@unmuhpnk.ac.id, \\ *Fakultas Agama Islam, Universitas Muhammadiyah Pontianak.
}

\begin{abstract}
The results showed that the average learning activity of students living in dormitories was 98.35 with a percentage of $78 \%$ (high), with an average visual activities of 21.53 with a percentage of $86 \%$ (high), oral activitis of 19.48 with a percentage $77 \%$ (high), listening activities at 20.93 with a percentage of $83 \%$ (high), writing activities of 17.69 with a percentage of $70 \%$ (high), and mental activities of 18.69 with a percentage of $74 \%$ (high). While the average learning activity of students living outside the dormitory was 72.12 with a percentage of $57 \%$ (moderate), with an average visual activities of 16.21 with a percentage of $77 \%$ (high), oral activities of 13.53 with a percentage of $77 \%$ (high), oral activities of 13.53 with a percentage of $77 \% 64 \%$ (high), listening activities at 15.46 with a percentage of $73 \%$ (high), writing activities of 12.19 with a percentage of $58 \%$ (moderate), and mental activities of 14.95 with a percentage of $71 \%$ (high). Thus the average study activity of students living in dormitories was 98.35 with a percentage of $78 \%$ (high), and students living outside the dormitory at 72.12 with a percentage of 57\% (moderate), with an average difference of 26,227 and a percentage difference of $21 \%$. Hypothetical test results show a t count value greater than the table $t(9,290>1,980)$. It can be concluded that there are significant differences in learning activities in Islamic Cultural History subjects between students living in dormitories and living outside the Private Madrasah Aliyah Dormitory (MAS) Yasti Singkawang in 2019/2020.
\end{abstract}

Keywords: Differences in Learning Activities, Dormitory, Outdoor Dorm

\section{PENDAHULUAN}

Aktivitas belajar merupakan kegiatan atau perilaku yang terjadi selama proses belajar meliputi aktivitas psikofisis yang menghasilkan kemampuan pengetahuan, sikap, dan keterampilan. Untuk meningkatkan aktivitas belajar siswa dibutuhkan pembelajaran yang efektif dan kondusif, dimana siswa diharapkan aktif melakukan semua aktivitas yang berlangsung selama proses pembelajaran. Aktivitas yang timbul dari siswa akan membuat terbentuknya pengetahuan, sikap dan keterampilan yang mengarah pada perubahan tingkah laku dan peningkatan prestasi. Dalam proses pembelajaran tentunya terdapat faktor internal dan eksternal yang mempengaruhi aktivitas belajar. Faktor internal meliputi kesehatan, bakat, motivasi dan cara belajar, sedangkan faktor eksternal meliputi lingkungan seperti lingkungan keluarga, sekolah, masyarakat.

Berdasarkan observasi yang dilakukan di Madrasah Aliyah Swasta (MAS) Yasti Singkawang yang bertepatan dengan pelaksanaan praktek pengalaman lapangan (PPL) dari bulan November 2019 hingga bulan Februari 2020, MAS Yasti yang terletak di Kota Singkawang ini merupakan sebuah sekolah yang baru disyahkan dalam bentuk pondok pesantren yang di dalamnya tidak hanya mempelajari ilmu agama Islam tetapi juga mempelajari dan mendalami ilmu umum. Sekolah ini memiliki 3 jurusan yaitu IPA, IPS dan Agama dengan jumlah 
siswa secara keseluruhan 323 orang. MAS Yasti merupakan sekolah yang menerapkan sistem asrama (boarding school) tetapi sistem tersebut tidak bersifat wajib bagi seluruh siswa, sehingga terdapat siswa yang tinggal di asrama dan siswa yang tinggal di luar asrama bersama orang tua atau keluarganya. Aktivitas belajar siswa di sekolah tentunya bisa berbeda dengan aktivitas belajar ketika mereka berada di luar sekolah atau di tempat tinggalnya.

Sesuai fakta melalui pengamatan yang dilakukan oleh peneliti di beberapa kelas yaitu kelas 11 MAS Yasti, pada proses pembelajaran mata pelajaran sejarah kebudayaan Islam, aktivitas belajar saat di kelas terlihat siswa yang pasif dan aktif atau antusias dalam mengikuti kegiatan belajar, mereka yang pasif mengikuti proses pembelajaran setelah diselidiki dikarenakan merasa mengantuk, bosan dengan materi pelajaran, kelelahan karena kurang tidur, bercerita dengan teman sebangku, mencoret-coret kertas, usil atau mengganggu teman, telat masuk kelas setelah beristirahat, tidak tertarik dengan pelajarannya sehingga menyebabkan mereka tidak memperhatikan, kurang tanggap terhadap pelajaran yang diberikan, ketika diberikan pertanyaan mereka kurang mampu untuk menjawab apalagi diminta untuk bertanya.

Berdasarkan paparan yang telah peneliti sampaikan, diuraikan beberapa permasalahan yang akan diteliti yaitu:

1. Bagaimana aktivitas belajar siswa dalam proses pembelajaran di sekolah bagi yang tinggal di asrama Madrasah Aliyah Swasta Yasti Singkawang?

2. Bagaimana aktivitas belajar siswa dalam proses pembelajaran bagi yang tinggal di luar asrama Madrasah Aliyah Swasta Yasti Singkawang?

3. Apakah terdapat perbedaan yang signifikan antara aktivitas belajar siswa dalam proses pembelajaran bagi yang tinggal di asrama dan di luar asrama Madrasah Aliyah Swasta Yasti Singkawang?

Metode yang digunakan dalam proses penelitian ini dengan cara menggambarkan keadaan subyek atau obyek penelitian pada saat sekarang berdasarkan fakta-fakta yang tampak atau sebagaimana adanya. Metode Komparatif digunakan untuk menguji ada tidaknya perbedaan yang signifikan antar variabel yang sedang diteliti. Sugiyono (2013: 57) mengemukakan bahwa metode komparatif merupakan jenis penelitian yang membandingkan keberadaan satu variabel atau lebih pada dua atau lebih sampel yang berbeda, atau pada waktu yang berbeda.

\section{Konsep Belajar}

Pengertian belajar menurut Dimyati dan Mudjiono (2015: 7) belajar merupakan tindakan dan perilaku siswa yang kompleks. (Slameto, 2013: 2) belajar merupakan suatu proses usaha yang dilakukan seseorang untuk memperoleh suatu perubahan tingkah laku yang baru secara keseluruhan sebagai hasil pengalamannya sendiri dalam berinteraksi dengan lingkungannya.

Berdasarkan beberapa pernyataan tersebut di atas, maka dapat disimpulkan bahwa belajar merupakan rangkaian kegiatan atau aktivitas psiko-fisik yang dilakukan secara sadar oleh seseorang dengan lingkungannya untuk memperoleh perubahan dalam dirinya dalam aspek kognitif, afektif, dan psikomotorik.

Allah telah menjelaskan dalam al-Qur'an surat anNahl ayat 78 yang berbunyi:

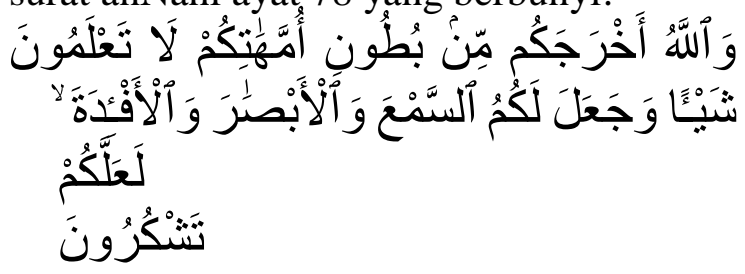

Artinya: "Allah telah mengeluarkanmu dari perut ibumu dalam keadaan tanpa sedikitpun pengetahuan, dan Allah memberimu pendengaran, penglihatan, dan hati agar kamu bersyukur".

Ayat tersebut menjelaskan bahwa belajar dalam perspektif Islam merupakan proses jasmani dan rohani untuk memperoleh ilmu pengetahuan dari proses pembelajaran yang akhirnya mengarah pada perubahan tingkah laku dan membentuk manusia yang seutuhnya. 


\section{Konsep Aktivitas Belajar}

Menurut Nanang Hanafiah dan Cucu Suhana (2012: 23) mengatakan aktivitas belajar adalah aktivitas yang melibatkan seluruh aspek psikofisis peserta didik, baik jasmani maupun rohani sehingga perubahan perilakunya dapat terjadi secara cepat, tepat, mudah, dan benar, baik berkaitan dengan aspek kognitif, afektif, maupun psikomotor. Aliwanto (2017: 69) mengatakan aktivitas belajar adalah aktivitas yang bersifat fisik maupun mental, dalam belajar kedua aktivitas tersebut harus saling berkaitan.

Jadi, aktivitas belajar merupakan kegiatan yang melibatkan aspek psiko-fisis yang melibatkan seluruh inderanya untuk memperoleh pengetahuan, keterampilan, perubahan tingkah laku, pemahaman yang terjadi secara cepat melalui pengalaman belajar dan mencakup aspek kognitif, afektif, dan psikomotorik.

Paul B. Diedric dalam Sardiman (2016: 101) mengatakan ada beberapa jenis/indikator aktivitas belajar yang harus dilakukan dengan baik oleh siswa untuk mencapai tujuan belajar yang maksimal diantaranya: 1) Visual activities, yaitu kegiatan membaca, memperhatikan, 2) Oral activities, yaitu kegiatan yang dilakukan seperti merumuskan, bertanya, memberi saran, berpendapat, diskusi, dan intruksi, 3) Listening activities yaitu kegiatan mendengarkan, 4) Writing activities yaitu kegiatan menulis, 5) Drawing activities, yaitu kegiatan menggambar, membuat grafik, peta dan diagram, 6) Motor activities, yaitu kegiatan melakukan pekerjaan, membuat konstruksi, model, 7) Mental activities yaitu kegiatan menanggapi, mengingat, memecahkan soal, menganalisis dan mengambil keputusan, 8) Emotional activities yaitu tenang, merasa bosan, gugup.

Slameto (2013: 54) mengemukakan mengenai beberapa faktor-faktor yang mempengaruhi aktivitas belajar siswa adalah sebagai berikut:

a) Faktor Internal
Faktor internal adalah faktor yang datang dari diri sendiri yaitu kemampuan yang dimiliknya, faktor kemampuan siswa memiliki pengaruh besar terhadap aktivitas belajar. Faktor internal dapat digolongkan menjadi: 1) Faktor Jasmaniah meliputi: kesehatan, cacat tubuh 2) Faktor Psikologis meliputi: intelegensia, perhatian, minat, bakat, motif, kematangan, kesiapan 3) Faktor kelelahan dibagi menjadi kelelahan jasmani seperti kurang tidur dan kurang istirahat, sedangkan kelelahan rohani seperti merasa kebosanan.

b) Faktor Eksternal

Faktor eksternal merupakan faktor yang timbul dari luar diri siswa yang sering dikatakan sebagai faktor sosial. Adapun faktor eksternal yang mempengaruhi aktivitas belajar adalah lingkungan. Lingkungan memberikan pengaruh positif jika dapat memberikan dorongan atau motivasi kepada anak untuk meningkatkan aktivitas belajarnya. Sebaliknya, lingkungan juga dapat memberikan pengaruh negatif apabila lingkungan disekitarnya tidak memberikan pengaruh yang baik dan justru akan menghambat aktivitas belajar tinggal (keluarga), lingkungan sekolah dan lingkungan masyarakat.

\section{Konsep Madrasah}

Madrasah secara harfiah berasal dari Bahasa Arab yang "sekolah" (school). Madrasah juga bisa diartikan sekolah. Asal katanya yaitu darasa yang artinya belajar. Madrasah juga bisa diartikan sekolah karena secara teknis keduanya memiliki kesamaan, yaitu sebagai tempat berlangsungnya proses belajar mengajar secara formal. Madrasah secara terminologi adalah nama atas sebutan bagi sekolahsekolah agama Islam, tempat proses belajar mengajar ajaran agama secara formal yang mempunyai kelas dan memiliki kurikulum Abdullah (2011: 30) mendefinisikan madrasah yaitu:

Madrasah merupakan sebuah lembaga pendidikan yang dirancang untuk pengajaran siswa atau murid di bawah 
pengawasan pendidik atau guru. Madrasah juga termasuk pendidikan umum yang berakar kuat dari partisipasi masyarakat selaras dengan identitas Negara kesatuan dalam keagamaan berdasarkan Ketuhanan Yang Maha Esa sebagian besar Negara memiliki sitem pendidikan formal yang umumnya wajib dalam upaya menciptakan anak didik yang mengalami kemajuan setelah mengalami proses melalui pembelajaran.

Siti Muri'ah dan Gianto (2020: 74) menyatakan bahwa: "madrasah merupakan suatu lembaga yang mengajarkan ilmu-ilmu keislaman". Dengan demikian maka madrasah merupakan sebuah tempat pendidikan atau wadah untuk mengajarkan ilmu-ilmu agama Islam dan juga ilmu pengetahuan umum guna memperoleh kecakapan dalam pengetahuan, bersikap dan keterampilan yang mengalami transformasi dalam berbagai sistem pendidikan dan berada di bawah kementerian agama.

\section{Konsep Asrama}

Menurut Irfan Setiawan (2013: 8) asrama merupakan sebuah tempat tinggal bagi siswa yang biasanya jauh dari rumah dan di dalamnya terdapat pembina asrama serta aturan yang terikat. Aturan tersebut dibuat agar siswa yang tinggal di asrama dapat mandiri dan disiplin dalam melakukan aktivitasnya.

Dengan demikian asrama merupakan tempat tinggal sekaligus tempat belajar bagi siswa yang tinggal jauh dari orang tuanya dengan waktu yang telah ditentukan dan semua aktivitas yang terjadi di asrama diawasi dan dibimbing oleh para guru atau pengasuh di asrama.

Sedangkan siswa yang tinggal di luar asrama asrama diartikan sebagai siswa yang tinggal bersama orang tua atau keluarga. Rumah atau lingkungan keluarga yang kondusif menentukan optimalisasi perkembangan pribadi, penyesuaian diri, kemampuan bersosialisasi, kecerdasan, kreativitas, moral, juga peningkatan kapasitas diri menuju kebaikan. Lingkungan tempat tinggal sudah pasti memiliki kekurangan dan kelebihannya masing-masing dan juga tergantung bagiamana setiap individu merespon atau menanggapi hal tersebut.

\section{PEMBAHASAN}

Aktivitas belajar merupakan kegiatan atau perilaku yang terjadi selama proses belajar. Terdapat delapan jenis/indicator aktivitas belajar yang harus dilakukan dengan baik oleh siswa untuk mencapai tujuan belajar yang maksimal diantaranya: 1) Visual activities, yaitu kegiatan membaca, memperhatikan, 2) Oral activities, yaitu kegiatan yang dilakukan seperti merumuskan, bertanya, memberi saran, berpendapat, diskusi, dan intruksi, 3) Listening activities yaitu kegiatan mendengarkan, 4) Writing activities yaitu kegiatan menulis, 5) Drawing activities, yaitu kegiatan menggambar, membuat grafik, peta dan diagram, 6) Motor activities, yaitu kegiatan melakukan pekerjaan, membuat konstruksi, model, 7) Mental activities yaitu kegiatan menanggapi, mengingat, memecahkan soal, menganalisis dan mengambil keputusan, 8) Emotional activities yaitu tenang, merasa bosan, gugup.

Pada penelitian ini peneliti hanya memfokuskan lima aktivitas belajar yaitu visual activities, oral activities, listening activities, writing activities, dan mental activities. Nanang Hanafiah dan Cucu Suhana (2012: 23) ${ }^{16}$ mengatakan aktivitas belajar adalah aktivitas yang melibatkan seluruh aspek psikofisis peserta didik, baik jasmani maupun rohani sehingga perubahan perilakunya dapat terjadi secara cepat, tepat, mudah, dan benar, baik berkaitan dengan aspek kognitif, afektif, maupun psikomotor.

Dari data yang diperoleh dan di analisis dari data mengenai aktivitas belajar yaitu visual activities (membaca, memperhatikan), oral activites 
(merumuskan, bertanya, memberi saran, berpendapat, diskusi), listening acitivities (mendengarkan), writing activities yaitu (kegiatan menulis) dan mental activities (kegiatan menanggapi, mengingat, memecahkan soal, menganalisis) menunjukkan bahwa aktivitas belajar siswa pada mata pelajaran Sejarah Kebudayaan Islam lebih unggul siswa yang tinggal di asrama dibandingkan siswa yang tinggal di luar asrama.

Berdasarkan data hasil skor angket aktivitas belajar Sejarah Kebudayaan Islam siswa yang tinggal di skor tertinggi adalah 25 dan skor terendah adalah 11. Skor total untuk visual activities sebesar 926, oral activities 838, listening activities 900, writing activities 761 , dan mental activities 804. Sedangkan data hasil skor angket aktivitas belajar Sejarah Kebudayaan Islam siswa yang tinggal di luar asrama pada tabel di atas, dapat diidentifikasi bahwa skor tertinggi adalah 25 dan skor terendah adalah 7. Skor total untuk visual activities sebesar 665, oral activities 555, listening activities 634, writing Activities 500, dan mental activities 613.

Selanjutnya skor masing-masing angket aktivitas belajar yang tinggal di asrama dan di luar asrama (MAS) Yasti Singkawang dicari nilai rata-rata (mean) dari setiap indikator penelitian tesebut yaitu

a. Nilai rata-rata (mean) Visual Activities siswa yang tinggal di asrama :

$\mathrm{X}_{1}=\frac{\sum X 1}{n 1}=\frac{926}{43}=21,53$

Siswa yang tinggal di luar asrama :

$\mathrm{X}_{2}=\frac{\sum X 1}{n 1}=\frac{665}{41}=16,21$

Untuk nilai rata-rata visual activities yaitu (kegiatan membaca, memperhatikan) pada siswa yang tinggal di asrama berdasarkan jumlah keseluruhan nilai yang dibagi jumlah siswa sebanyak 43 dan 41 siswa, rata-rata skor visual activities siswa yang tinggal di asrama sebesar 21,53 dan skor visual activities pada siswa yang tinggal di luar asrama sebesar 16,21. Dengan demikian bahwa visual activities siswa yang tinggal di asrama lebih baik dibandingkan visual activities siswa yang tinggal di luar asrama

b. Nilai rata-rata (mean) Oral Activities

$\mathrm{X}_{2}=\frac{\sum X 2}{n 1}=\frac{838}{43}=19,48$

Siswa yang tinggal di luar asrama :

$\mathrm{X}_{2}=\frac{\sum X 2}{n 1}=\frac{555}{41}=13,53$

Untuk nilai rata-rata oral activities yaitu (kegiatan bertanya, memberi saran, berpendapat, diskusi) pada siswa yang tinggal di asrama berdasarkan jumlah keseluruhan nilai yang dibagi jumlah siswa sebanyak 43 dan 41 siswa, ratarata skor oral activities siswa yang tinggal di asrama sebesar 19,48 dan skor oral activities pada siswa yang tinggal di luar asrama sebesar 13,53. Dengan demikian bahwa oral activities siswa yang tinggal di asrama lebih baik dibandingkan oral activities siswa yang tinggal di luar asrama

c. Nilai rata-rata (mean) Listening Activities

$\mathrm{X}_{3}=\frac{\sum X 3}{n 1}=\frac{900}{43}=20,93$

Siswa yang tinggal di luar asrama :

$\mathrm{X}_{3}=\frac{\sum X 3}{n 1}=\frac{634}{41}=15,46$

Untuk nilai rata-rata listening activities yaitu (kegiatan mendengarkan) pada siswa yang tinggal di asrama berdasarkan jumlah keseluruhan nilai yang dibagi jumlah siswa sebanyak 43 dan 41 siswa, rata-rata skor listening activities siswa yang tinggal di asrama sebesar 20,93 dan skor listening activities pada siswa yang tinggal di luar asrama sebesar 15,46. Dengan demikian bahwa listening activities siswa yang tinggal di asrama lebih baik dibandingkan listening activities siswa yang tinggal di luar asrama

d. Nilai rata-rata (mean) Writing Activities $\mathrm{X}_{4}=\frac{\sum X 4}{n 1}=\frac{761}{43}=17,69$

Siswa yang tinggal di luar asrama : $\mathrm{X}_{4}=\frac{\sum X 4}{n 1}=\frac{500}{41}=12,19$

Untuk nilai rata-rata writing activities yaitu (kegiatan menulis) pada siswa yang tinggal di asrama berdasarkan jumlah keseluruhan nilai yang dibagi jumlah siswa sebanyak 43 
dan 41 siswa, dengan rata-rata skor writing activities siswa yang tinggal di asrama sebesar 17,69 dan skor writing activities pada siswa yang tinggal di luar asrama sebesar 12,19. Dengan demikian bahwa writing activities siswa yang tinggal di asrama lebih baik dibandingkan writing activities siswa yang tinggal di luar asrama

e. Nilai rata-rata (mean) Mental Activities

$\mathrm{X}_{5}=\frac{\sum X 5}{n 1}=\frac{804}{43}=18,69$

Siswa yang tinggal di luar asrama :

$\mathrm{X}_{5}=\frac{\sum X 5}{n 1}=\frac{613}{41}=14,95$

Untuk nilai rata-rata mental activities yaitu (kegiatan menanggapi, mengingat, memecahkan soal, menganalisis dan mengambil keputusan) pada siswa yang tinggal di asrama berdasarkan jumlah keseluruhan nilai yang dibagi jumlah siswa sebanyak 43 dan 41 siswa, rata-rata skor mental activities siswa yang tinggal di asrama sebesar 18,69 dan skor mental activities pada siswa yang tinggal di luar asrama sebesar 14,95. Dengan demikian bahwa mental activities siswa yang tinggal di asrama lebih baik dibandingkan mental activities siswa yang tinggal di luar asrama

Jumlah sampel (n) dalam penelitian ini terbagi dua yaitu $\mathrm{n}_{1}=43$ dan $\mathrm{n}_{2}=41$, maksudnya jumlah sample MAS YAsti yang tinggal di asrama 43 siswa dan jumlah siswa MAS Yasti yang tidak asrama 41 siswa. Nilai rata-rata $(\mathrm{X})$ yang diperoleh siswa MAS Yasti bagi yang tinggal di asrama adalah 98,35 dan bagi siswa yang tidak tinggal di asrama adalah 72,12. Varian $\left(\mathrm{S}^{2}\right)$ bagi siswa MAS Yasti yang tinggal di asrama adalah 153,852 sedangkan siswa yang tidak tinggal di asrama adalah 181,360. Standar deviasi (s) bagi siswa yang tinggal di asrama adalah 12,40 sedangkan siswa yang tidak tinggal di asrama adalah 13,46 . Nilai minimum bagi siswa yang tinggal di asrama adalah 69 dan bagi siswa yang tidak tinggal di asrama adalah 49. Nilai maksimal bagi siswa yang tinggal di asrama adalah 125 dan bagi siswa yang tidak tinggal di asrama adalah 112.
Nilai modus (mo) bagi siswa yang tinggal di asrama adalah 102 dan bagi siswa yang tidak tinggal di asrama adalah 80. Nilai median (me) bagi siswa yang tinggal di asrama adalah 98 dan bagi siswa yang tidak tinggal di asrama adalah 73.

Kemudian dari data yang diperoleh dan di analisis dengan menggunakan uji perbandingan maka di ketahui terdapat perbedaan yang signifikan aktivitas belajar antara siswa yang tinggal di asrama dan siswa yang tinggal di luar asrama MAS YAsti Singkawang. Pada hasil perhitungan tersebut rata-rata skor hasil angket aktivitas belajar bagi siswa yang tinggal di asrama yaitu 98,35 dengan persentase 78\% (tinggi) lebih tinggi dari pada skor aktivitas belajar siswa yang tinggal di luar asrama yaitu 72,12 dengan persentase $57 \%$ (sedang), dengan perbedaan rata-rata sebesar 26,227 dan perbedaan persentase sebesar $21 \%$.

Berdasarkan hal tersebut di atas tentunya siswa yang tinggal di dalam asrama saat berada di dalam asrama aktivitas belajarnya dapat dikontrol atau diawasi oleh pembimbing, selain itu belajar dapat dilakukan secara berkelompok dan juga kegiatan belajar dapat lebih sering dilakukan sehingga saat mengikuti aktivitas belajar di dalam kelas siswa yang tinggal di asrama cenderung lebih aktif karena sudah mempelajari terlebih dahulu materi yang akan di sampaikan pada proses pembelajaran di kelas.

\section{PENUTUP}

\section{Kesimpulan}

Berdasarkan pembahasan yang telah diuraikan maka dapat disimpulkan sebagai berikut:

1. Aktivitas belajar siswa yang tinggal di asrama terdiri dari lima aktivitas yaitu: visual activities, oral activities, listening activities, writing activities, dan mental activities lebih unggul atau lebih baik dari pada siswa yang tinggal di luar asrama. Rata-rata aktivitas belajar siswa yang tinggal di asrama yaitu 98,35 dengan persentase $78 \%$ (tinggi), dengan rata-rata visual activities sebesar 21,53 dengan 
persentase $86 \%$ (sangat tinggi), oral activities sebesar 19,48 dengan persentase $77 \%$ (tinggi), listening activities sebesar 20,93 dengan persentase $83 \%$ (Sangat tinggi), writing activities sebesar 17,69 dengan persentase $70 \%$ (tinggi), dan mental activities sebesar 18,69 dengan persentase $74 \%$ (tinggi).

2. Aktivitas belajar siswa yang tinggal di luar asrama terdiri dari lima aktivitas yaitu: visual activities, oral activities, listening activities, writing activities, dan mental activities tidak lebih unggul atau tidak lebih baik dari pada siswa yang tinggal di asrama. Rata-rata aktivitas belajar siswa yang tinggal di luar asrama yaitu 72,12 dengan persentase $57 \%$ (sedang), dengan ratarata visual activities sebesar 16,21 dengan persentase $77 \%$ (tinggi), oral activities sebesar 13,53 dengan persentase $64 \%$ (tinggi), listening activities sebesar 15,46 dengan persentase $73 \%$ (tinggi), writing activities sebesar 12,19 dengan persentase $58 \%$ (sedang), dan mental activities sebesar 14,95 dengan persentase $71 \%$ (tinggi).

3. Terdapat perbedaan signifikan antara aktivitas belajar siswa yang tinggal di asrama dan siswa yang tinggal di luar asrama MAS Yasti, dengan diperoleh nilai $\mathrm{t}$ hitung $>\mathrm{t}$ tabel $(9,290>1,980)$ dengan dengan hasil rata-rata persentase menunjukkan siswa yang tinggal di asrama lebih unggul dengan nilai rata-rata 98,35 dengan persentase sebesar 78\% (tinggi) sedangkan siswa yang tinggal di luar asrama dengan nilai rata-rata 72,12 dengan persentase sebesar $57 \%$ (sedang). Setiap siswa memiliki aktivitas belajar yang beraneka ragam untuk menunjukkan respon atau reaksinya terhadap objek tertentu yang memberikan rangsangan atau stimulus pada dirinya. Hal tersebut dapat diketahui dari aktivitas belajar pada saat proses pembelajaran berlangsung, dari aktivitas bertanya, mencatat, berdiskusi pada saat mata pelajaran Sejarah Kebudayaan Islam.

\section{Saran}

Berdasarkan uraian hasil penelitian yang telah dilakukan, maka peneliti dapat menyarankan sebagai berikut:

1. Kepada siswa, diharapkan untuk lebih meningkatkan aktivitas belajar menjadi lebih baik, dan tidak menjadikan perbedaan sebagai hambatan untuk menjalin komunikasi. Hilangkan pikiran bahwa anak yang tinggal di asrama jauh lebih baik dari pada anak yang tinggal di luar asrama. Tunjukkan bahwa dalam proses pembelajaran dapat menunjukkan kemampuan masing-masing.

2. Kepada guru mata pelajaran Sejarah kebudayaan Islam, diharapkan dapat menyeimbangkan perhatiannya kepada siswa yang tinggal di asrama dan siswa yang tinggal di luar asrama. Jangan menjadikan tolak ukur bahwa siswa yang tinggal di asrama akan lebih baik daripada siswa yang tinggal di luar asrama. Berikan dukungan atau motivasi kepada siswa agar mereka dapat meningkatkan kemampuan dan potensi yang sama. Gunakan metode pembelajaran yang dapat menimbulkan minat atau daya tarik pada mata pelajaran Sejarah Kebudayaan Islam, dan ciptakanlah suasana belajar yang menyenangkan agar siswa tidak merasa bosan.

3. Kepada Kepala Sekolah, diharapkan dapat memberikan dukungan penuh pada semua siswa, dan memberikan fasilitas yang sama 


\section{DAFTAR PUSTAKA}

Abdullah (2011). Sosiologi Pendidikan (Individu, Masyarakat, dan Pendidikan). Jakarta: PT Raja Grafindo Persada

Aliwanto (2017). Analisis Aktivitas Belajar Siswa. Volume 3 Nomor 1. Jurnal Konseling GUSJIGANG. Pontianak: IKIP PGRI

Dimyati dan Mudjiono (2009). Belajar Dan Pembelajaran. Jakarta: Rineka Cipta

Departemen Agama RI (2015). Al-Qur'an Terjemahan. Bandung: CV Darus Sunnah

Irfan Setiawan (2013). Perbedaan dan Pengembangan Peserta Didik Pada Institusi Berasrama. Yogyakarta: CV. Smart Writing
Nanang Hanafiah dan Cucu Suhana (2012). Konsep Strategi Pembelajaran. Bandung: PT Refika Aditama

Sardiman (2016). Interaksi dan Motivasi Belajar Mengajar. Depok: Rajawali Pers

Siti Muri'ah dan Gianto (2020). Kekerasan Simbolik di Madrasah. Ponorogo: Myria Publisher

Slameto (2013). Belajar dan Faktor-Faktor yang Mempengaruhinya. Jakarta: Rineka Cipta

Sugiyono (2013). Metode Penelitian Pendidikan. Bandung: Alfabeta 